\title{
THERMODYNAMIC PROPERTIES OF SOLUTIONS OF THE ACRYLIC ACID IN 1,2-DICHLOROETHANE AND ACETIC ACID
}

\author{
Lviv Polytechnic National University, \\ 12, St. Bandery str.,79013 Lviv, Ukraine; vsergeev@polynet.Iviv.ua
}

Received: N ovember 01, 2010 / Revised: December 29, 2010 / Accepted: March 16, 2011

(c) Serheyev V., Kos Yu., Van-Chin-Syan Yu., 2011

\begin{abstract}
The saturated vapor pressure of the acrylic acid solutions in 1,2-dichloroethane and acetic acid was measured by static tensimetric method in the temperature range of 295 to $355 \mathrm{~K}$. The composition of the equilibrium phases as well as the activity coefficients $\left(\gamma_{1}\right.$ and $\left.\gamma_{2}\right)$ were received from the experimental measurements of the temperature-dependent saturated vapor pressure. Then we used the temperature and concentration dependent activity coefficients to calculate the excess thermodynamic functions of the solutions mixing $\left(\mathrm{H}^{\mathrm{E}}, \mathrm{G}^{\mathrm{E}}, \mathrm{S}^{\mathrm{E}}\right)$.
\end{abstract}

Keywords: acrylic acid, saturated vapor pressure, activity coefficients, vapor-liquid equilibrium, excess thermodynamic functions of mixing.

\section{Introduction}

Acrylic-based acids and esters are attractive classes of raw materials because of the wide range of polymers properties synthesized on their basis. The thermodynamic properties of the individual neat components have been extensively studied [1-3].

There have also been a number of studies of the liquid-vapor equilibrium of acrylic acid and their ethers solutions. Most works [4-12] focused on the liquid-vapor equilibrium for solutions of acrylic, methacrylic and ethacrylic acids and their ethers under isobaric conditions and an ambient pressure. Based on the experimental values, parameters of the Local Composition Models (Wilson equation [13], NRTL equation [14], UNIQUAC equation [15]) were evaluated. These equations may be used to calculate the liquid-vapor equilibrium at different pressures. In this work the excess thermodynamic functions of solutions mixing based on the experimental data of the temperature dependent vapor pressure upon solutions of acrylic acid in 1,2-dichloroethane and acetic acid have been calculated. A particular utility of our data is that they can be used to directly calculate the composition of the equilibrium phases for investigational systems within the temperature and pressure ranges studies.

Such studies of liquid-vapor equilibrium are useful, as they should provide the necessary information on the behavior of the individual components in these complex systems. In this work, to estimate the thermodynamic functions of mixing based on the vapor-liquid equilibrium, we adopted the commonly used methodology developed by Belousov and Morachevsky [16, 17].

\section{Experimental}

The raw materials were of the commercial grade and were supplied by MERCK (Germany). The chemicals received were further purified by means of multiple distillation and acrylic and acetic acids additionally by recrystallization. The chemicals were then selected based on their unique boiling temperature as well as the refractive index. The contamination was kept below $0.2 \mathrm{wt} \%$, as verified through chromatography.

Experimental measurements of the vapor pressure over solutions at various temperatures were at the basis of our static methodology approach.

The experimental setup shown in Fig. 1 comprised: $20 \mathrm{ml}$ glass flask (1) connected to the pressure sensor (4) via the connector (2) with the Teflon gasket (3). Valve (5) was used to adjust the vacuum level in the flask. All of the metallic parts in contact with solutions were gold-plated, to prevent the undesired chemical interactions. The pressure sensor (Sensor Technics CTE8N01) contained a Silicon membrane (7) with the data acquisition accuracy of $0.3 \mathrm{~Pa}$. Voltmeter (6) was used to collect the pressure readings (with the data acquisition accuracy of $0.0005 \mathrm{~V}$, which is equivalent to $15 \mathrm{~Pa}$ ). The sensor was calibrated using a Ushaped mercury manometer (with the standard measurement error of $\pm 32 \mathrm{~Pa}$ ). The correlation between the manometer and voltmeter readings was linear, with the correlation coefficient of 0.9999 . 


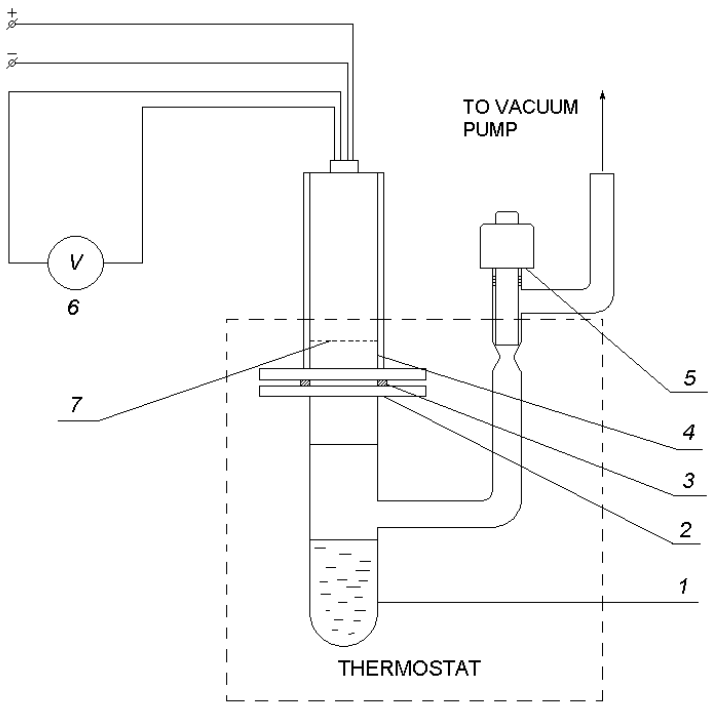

Fig. 1. Experimental setup for vapor pressure measurements

Experiments were conducted using approximately $10 \mathrm{ml}$ of solution. We cooled the system to $250 \mathrm{~K}$ and kept it under vacuum, to minimize evaporation. Then, after releasing the vacuum, we should again heat up the system to $360 \mathrm{~K}$, to decrease the amount of dissolved gas. Next, we should again cool the system, to remove the residual vapor. This protocol was repeated several times (typically, about five times), to ensure the residual pressure in the system would be no greater than $10 \mathrm{~Pa}$.

The test setup was placed in the thermostat, as shown in Fig. 1. Having varied the temperature in a controlled fashion (with the resolution accuracy of $0.1 \mathrm{~K}$ ), from 295 to $355 \mathrm{~K}$, we collected the saturated vapor pressure data. It was considered that the equilibrium was reached when the vapor pressure would not change for a period of time at least $15 \mathrm{~min}$. Since the liquid-to-gas volume ratio in our experiment was kept at 1:1, the compositional change in the liquid phase due to the evaporation of the most volatile component would always be less than $0.2 \mathrm{~mol} \%$ [23].

First, we verified our measurement methodology, as well as the correctness of our approach, by conducting series of experiments with well-known substances such as heptane and hexane. The results obtained using these chemicals matched closely the reported literature data [18].

\section{Results and Discussion}

Next, to test our experimental systems we prepared several solutions with the concentration ranging from 20 to $80 \%$. Notably, to prevent the undesired polymerization of the acrylic acid we inhibited the systems by adding about $0.2 \mathrm{~mol} \%$ of ionol. We further verified that when added in this minuscule amount, ionol did not influence the measurements. The concentration of the solutions was measured using chromatography in the end of an experiment, after the system reached the room temperature. These data, as well as the temperature dependent saturated vapor pressure, are reported in Table 1. The concentration data show the most volatile component of the solution (1,2dichloroethane or acetic acid).

Table 1

Dependence of the vapor pressure upon temperature

\begin{tabular}{|c|c|c|c|c|c|c|c|}
\hline$T, \mathrm{~K}$ & $P, \mathrm{kPa}$ & $T, \mathrm{~K}$ & $P, \mathrm{kPa}$ & $T, \mathrm{~K}$ & $P, \mathrm{kPa}$ & $T, \mathrm{~K}$ & $P, \mathrm{kPa}$ \\
\hline \multicolumn{8}{|c|}{ 1,2-dichloroethane - acrylic acid } \\
\hline \multicolumn{2}{|c|}{$17.72 \pm 0.77$} & \multicolumn{2}{|c|}{$34.50 \pm 0.54$} & \multicolumn{2}{|c|}{$53.41 \pm 0.70$} & \multicolumn{2}{|c|}{$77.85 \pm 0.62$} \\
\hline 297.2 & 3.94 & 298.1 & 6.12 & 294.8 & 7.04 & 292.6 & 7.83 \\
\hline 297.6 & 4.28 & 306.2 & 9.10 & 305.4 & 11.55 & 303.7 & 12.88 \\
\hline 304.1 & 5.76 & 315.3 & 13.42 & 314.9 & 17.28 & 303.9 & 13.14 \\
\hline 315.3 & 9.27 & 323.3 & 18.24 & 325.4 & 26.05 & 314.3 & 20.31 \\
\hline 324.3 & 13.12 & 334.5 & 27.75 & 333.5 & 35.28 & 323.9 & 29.56 \\
\hline 333.8 & 19.04 & 341.3 & 35.32 & 342.9 & 49.7 & 334.8 & 44.26 \\
\hline 341.5 & 25.28 & 348.3 & 45.29 & 353.2 & 70.31 & 342.4 & 58.08 \\
\hline 353.6 & 38.37 & 355.9 & 58.29 & & & 354.1 & 85.17 \\
\hline \multicolumn{8}{|c|}{ Acetic acid - acrylic acid } \\
\hline \multicolumn{2}{|c|}{$21.63 \pm 0.35$} & \multicolumn{2}{|c|}{$40.11 \pm 0.59$} & \multicolumn{2}{|c|}{$60.28 \pm 0.78$} & \multicolumn{2}{|c|}{$79.42 \pm 0.73$} \\
\hline 299.8 & 1.75 & 293.0 & 1.66 & 294.9 & 2.04 & 294.6 & 2.13 \\
\hline 304.1 & 2.04 & 303.6 & 2.82 & 304.2 & 3.22 & 304.2 & 3.31 \\
\hline 313.5 & 3.05 & 314.4 & 4.45 & 304.3 & 3.31 & 314.6 & 5.04 \\
\hline 324.2 & 4.83 & 323.3 & 6.39 & 314.2 & 4.83 & 323.7 & 7.65 \\
\hline 324.3 & 4.87 & 333.8 & 9.43 & 323.5 & 7.27 & 333.5 & 11.49 \\
\hline 333.7 & 7.06 & 343.2 & 13.35 & 333.2 & 10.65 & 341.4 & 15.08 \\
\hline 344.2 & 10.19 & 343.3 & 13.52 & 343.8 & 15.88 & 344.8 & 17.04 \\
\hline 354.6 & 14.53 & 352.8 & 18.66 & 354.1 & 22.42 & 355.3 & 24.52 \\
\hline
\end{tabular}


Fitting coefficients of Eq. (1)

\begin{tabular}{|c|c|c|c|c|}
\hline$x$, mol \% & $A$ & $B \cdot 10^{-2}$ & $T, \mathrm{~K}$ & $\rho$ \\
\hline \multicolumn{5}{|c|}{1,2 -dichloroethane - acrylic acid } \\
\hline 100 & $23.01 \pm 0.09$ & $40.09 \pm 0.29$ & $297.9-359.4$ & 0.9998 \\
\hline $77.85 \pm 0.62$ & $22.73 \pm 0.07$ & $40.26 \pm 0.23$ & $292.6-354.0$ & 0.9999 \\
\hline $53.41 \pm 0.70$ & $22.69 \pm 0.29$ & $40.73 \pm 0.93$ & $294.8-353.2$ & 0.9997 \\
\hline $34.50 \pm 0.54$ & $22.50 \pm 0.33$ & $41.0 \pm 1.1$ & $298.1-355.9$ & 0.9999 \\
\hline $17.72 \pm 0.77$ & $22.33 \pm 0.61$ & $41.6 \pm 1.9$ & $297.2-353.6$ & 0.9999 \\
\hline 0 & $24.26 \pm 0.28$ & $52.75 \pm 0.81$ & $294.5-352.5$ & 0.9998 \\
\hline \multicolumn{5}{|c|}{ Acetic acid - acrylic acid } \\
\hline 100 & $24.08 \pm 0.11$ & $49.09 \pm 0.34$ & $295.0-356.7$ & 0.9999 \\
\hline $79.42 \pm 0.73$ & $22.07 \pm 0.71$ & $42.49 \pm 0.89$ & $294.6-355.3$ & 0.9999 \\
\hline $60.28 \pm 0.78$ & $21.93 \pm 0.29$ & $42.17 \pm 0.93$ & $294.5-354.1$ & 0.9999 \\
\hline $40.11 \pm 0.59$ & $21.63 \pm 0.16$ & $41.62 \pm 0.52$ & $293.0-352.8$ & 0.9999 \\
\hline $21.63 \pm 0.35$ & $21.33 \pm 0.49$ & $41.03 \pm 0.96$ & $299.8-354.6$ & 0.9999 \\
\hline 0 & $24.26 \pm 0.28$ & $52.75 \pm 0.81$ & $294.5-352.5$ & 0.9998 \\
\hline
\end{tabular}

We used Eq. (1) to fit the experimental data of the temperature dependent saturated vapor pressure, as well as the literature data of the individual components $[1,18]$ :

$$
\ln P=A-B / T
$$

The fitting coefficients, along with the correlation coefficients $\rho$, evaluated in a given temperature range are listed in Table 2.Having received the functional dependences of the saturated vapor pressure on the temperature for several concentrations of the acrylic acid in each solvent, enabled us to create the isothermal sections of the saturated vapor pressure as a function of the concentration. The system the acetic acid - the acrylic acid contains the azeotrope with a minimum boiling temperature. The properties of this azeotrope were investigated in [24]. The dependence of the saturated vapor pressure on the acrylic acid concentration was fit using polynomial, whereby the polynomial order was chosen based on the magnitude of standard deviation between the experimental and the fitted values. The polynomial order was considered acceptable when the standard deviation was comparable to the experimental error.

Further, we calculated the partial vapor pressure of the components $\left(p_{1}\right.$ and $\left.p_{2}\right)$ using the Duhem-Margules equation (Eq. (2)), assuming the gas phase was close to an ideal gas phase:

$$
x d \ln p_{1}+(1-x) d \ln p_{2}=0
$$

Eq. (2) may be rewritten as follows:

$$
d p-p \cdot x \cdot \frac{d p}{p_{1}}-\frac{d p}{d x} \cdot(1-x) \cdot d x=0
$$

To solve Eq. (3), we substituted $d x$ and $d p_{1}$ with $\Delta x$ and $\Delta p_{1}$ :

Table 2

$$
\Delta p_{1}\left(1-\frac{p}{p_{1}} \cdot x\right)-\frac{d p}{d x} \cdot(1-x) \cdot \Delta x=0
$$

Eq. (4) was solved by the Runge method, integrating in the direction of the increased pressure.

Table 3

\section{Equilibrium composition, partial vapor pressure and activity coefficients of 1,2-dichloroethane in the acrylic acid}

\begin{tabular}{|c|c|c|c|c|c|}
\hline$x$ & $y$ & $p_{1}$ & $p_{2}$ & \multirow{2}{*}{$\gamma_{1}$} & \multirow{2}{*}{$\gamma_{2}$} \\
\hline \multicolumn{7}{|c|}{$\mathrm{kPa}$} & & \\
\hline \multicolumn{7}{|c|}{$300 \mathrm{~K}$} \\
\hline 0 & 0 & 0.63 & 0.63 & - & 1.000 \\
\hline 10.0 & 73.6 & 0.79 & 2.99 & 1.855 & 1.001 \\
\hline 20.0 & 85.2 & 0.71 & 4.81 & 1.725 & 1.014 \\
\hline 30.0 & 90.0 & 0.64 & 6.37 & 1.604 & 1.039 \\
\hline 40.0 & 92.6 & 0.57 & 7.67 & 1.491 & 1.081 \\
\hline 50.0 & 94.2 & 0.50 & 8.75 & 1.386 & 1.148 \\
\hline 60.0 & 95.4 & 0.44 & 9.65 & 1.290 & 1.255 \\
\hline 70.0 & 96.4 & 0.38 & 10.38 & 1.201 & 1.434 \\
\hline 80.0 & 97.2 & 0.31 & 10.98 & 1.121 & 1.768 \\
\hline 90.0 & 98.0 & 0.23 & 11.48 & 1.051 & 2.593 \\
\hline 100 & 100 & 0 & 11.85 & 1.000 & - \\
\hline \multicolumn{7}{|c|}{$350 \mathrm{~K}$} \\
\hline 0 & 0 & 2.14 & 2.14 & - & 1.000 \\
\hline 10.0 & 62.0 & 9.05 & 23.82 & 1.756 & 1.003 \\
\hline 20.0 & 77.0 & 8.16 & 35.51 & 1.625 & 1.017 \\
\hline 30.0 & 83.9 & 7.32 & 45.35 & 1.505 & 1.043 \\
\hline 40.0 & 87.8 & 6.54 & 53.59 & 1.397 & 1.086 \\
\hline 50.0 & 90.4 & 5.78 & 60.48 & 1.299 & 1.153 \\
\hline 60.0 & 92.4 & 5.03 & 66.31 & 1.213 & 1.254 \\
\hline 70.0 & 94.0 & 4.25 & 71.33 & 1.138 & 1.413 \\
\hline 80.0 & 95.6 & 3.36 & 75.81 & 1.076 & 1.677 \\
\hline 90.0 & 97.3 & 2.20 & 80.02 & 1.027 & 2.196 \\
\hline 100 & 100 & 0 & 84.20 & 1.000 & - \\
\hline
\end{tabular}


Table4

Equilibrium composition, partial vapor pressure and the activity coefficients of the acetic acid in the acrylic acid

\begin{tabular}{|c|c|c|c|c|c|}
\hline$x$ & $y$ & $P_{1}$ & $P_{2}$ & \multirow{2}{*}{$\gamma_{1}$} & \multirow{2}{*}{$\gamma_{2}$} \\
\hline \multicolumn{2}{|c|}{ mol \% } & \multicolumn{2}{|c|}{$\mathrm{kPa}$} & & \\
\hline \multicolumn{6}{|c|}{$300 \mathrm{~K}$} \\
\hline 0 & 0 & 0.63 & 0.63 & - & 1.000 \\
\hline 10.0 & 43.5 & 0.71 & 1.26 & 2.275 & 1.002 \\
\hline 20.0 & 61.8 & 0.64 & 1.68 & 2.140 & 1.013 \\
\hline 30.0 & 71.7 & 0.57 & 2.02 & 1.999 & 1.037 \\
\hline 40.0 & 77.8 & 0.51 & 2.30 & 1.853 & 1.081 \\
\hline 50.0 & 81.8 & 0.46 & 2.52 & 1.700 & 1.160 \\
\hline 60.0 & 83.4 & 0.41 & 2.65 & 1.541 & 1.311 \\
\hline 70.0 & 83.7 & 0.39 & 2.71 & 1.372 & 1.631 \\
\hline 80.0 & 84.5 & 0.07 & 2.70 & 1.175 & 2.646 \\
\hline 90.0 & 97.4 & 0.09 & 2.62 & 1.164 & 7.643 \\
\hline 100 & 100 & 0 & 2.42 & 1.000 & - \\
\hline \multicolumn{6}{|c|}{$350 \mathrm{~K}$} \\
\hline 0 & $\overline{0}$ & 2.14 & 2.14 & - & 1.000 \\
\hline 10.0 & 21.4 & 8.06 & 10.25 & 0.938 & 0.976 \\
\hline 20.0 & 43.7 & 6.92 & 12.30 & 1.151 & 0.943 \\
\hline 30.0 & 59.7 & 5.90 & 14.63 & 1.246 & 0.919 \\
\hline 40.0 & 69.9 & 5.04 & 16.77 & 1.255 & 0.917 \\
\hline 50.0 & 76.4 & 4.35 & 18.41 & 1.204 & 0.949 \\
\hline 60.0 & 80.4 & 3.82 & 19.49 & 1.118 & 1.041 \\
\hline 70.0 & 83.1 & 3.39 & 20.10 & 1.022 & 1.233 \\
\hline 80.0 & 86.4 & 2.80 & 20.58 & 0.951 & 1.524 \\
\hline 90.0 & $\begin{array}{l}93.9 \\
\end{array}$ & 1.31 & 21.42 & 0.957 & 1.425 \\
\hline 100 & 100 & 0 & 23.32 & 1.000 & - \\
\hline
\end{tabular}

The calculation of the partial vapor pressure of each component, $p_{1}$ and $p_{2}$, allowed us to arrive to the composition of the gas phase as well as the activity coefficients of the components $\left(\gamma_{1}\right.$ and $\left.\gamma_{2}\right)$, in the temperature range from 300 to $350 \mathrm{~K}$. Tables 3 and 4 list the composition of the liquid phase $(x)$, gas phase $(y)$, vapor pressure of components $p_{1}$ and $p_{2}$, as well as the activity coefficients $\gamma_{1}$ and $\gamma_{2}$ at the minimum and maximum temperature of the experiment.

To describe the properties of the non-ideal solutions we used the excess thermodynamic functions of mixing and calculated the differential between the functions of mixing of the experimental and the ideal solutions. For instance, the Gibbs energy of mixing is calculated based on $\gamma_{1}$ and $\gamma_{2}$ :

$$
G^{E}=R T\left(x_{1} \ln \gamma_{1}+x_{2} \ln \gamma_{2}\right)
$$

The enthalpy of our systems mixing is then calculated based on $\gamma_{1}$ and $\gamma_{2}$ at different temperatures:

$$
\Delta H^{E}=-R T^{2} \cdot\left[x_{1} \cdot\left(\frac{\partial \ln \gamma_{1}}{\partial T}\right)_{x}+x_{2} \cdot\left(\frac{\partial \ln \gamma_{2}}{\partial T}\right)_{x}\right](6)
$$

Finally, one may evaluate the entropy of mixing:

$$
T \Delta S^{E}=\Delta H^{E}-\Delta G^{E}
$$

The results of these calculations are shown in Fig. 2.

The role of the solvent has been studied in detail elsewhere $[19,20]$. We aimed to investigate how the Dimroth-Reichardt [21] parameter $E_{T}^{N}$, the acceptor number $A N$ [22], and the molecular refraction $R_{M}$ depend on the thermodynamic functions of equimolecular solutions formation of the acrylic acid at $350 \mathrm{~K}$.

Properties of solvents and solutions

Table 5

\begin{tabular}{|l|c|c|c|c|c|}
\hline \multicolumn{1}{|c|}{ Solvent } & $E_{T}^{N}$ & $A N$ & $R_{M}$ & $H^{E}{ }_{350}, \mathrm{~kJ} / \mathrm{mol}$ & $G_{350}^{E}, \mathrm{~kJ} / \mathrm{mol}$ \\
\hline 1,2-dichloroethane & 0.327 & 16.7 & -19.33 & 1.07 & 0.59 \\
\hline Acetic acid & 0.648 & 52.9 & -10.90 & 1.57 & 0.98 \\
\hline
\end{tabular}

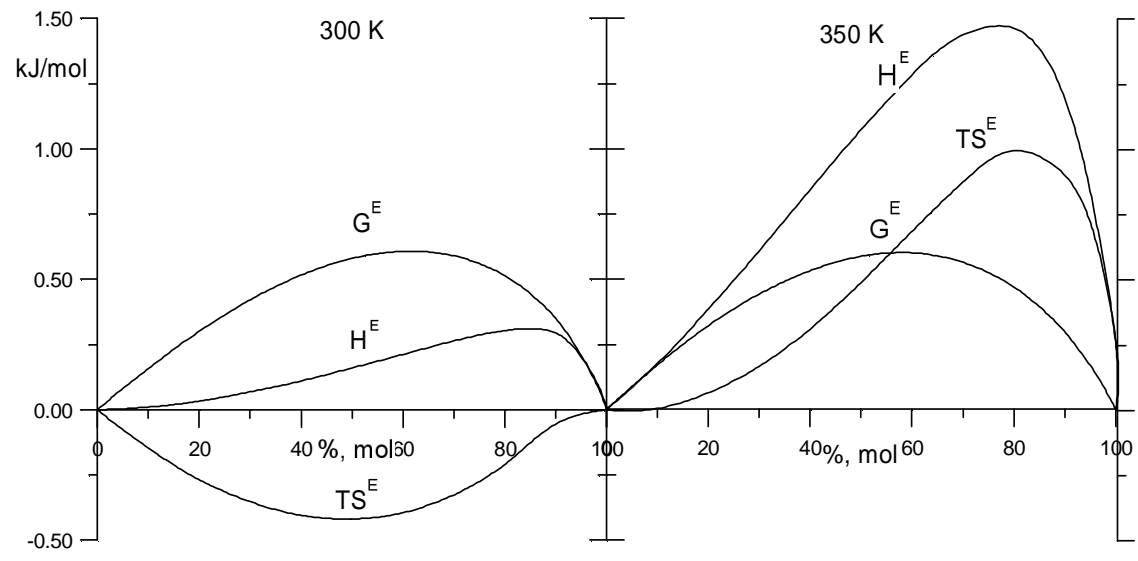

Fig. 2a. The thermodynamic functions of mixing of the 1,2-dichloroethane in the acrylic acid 


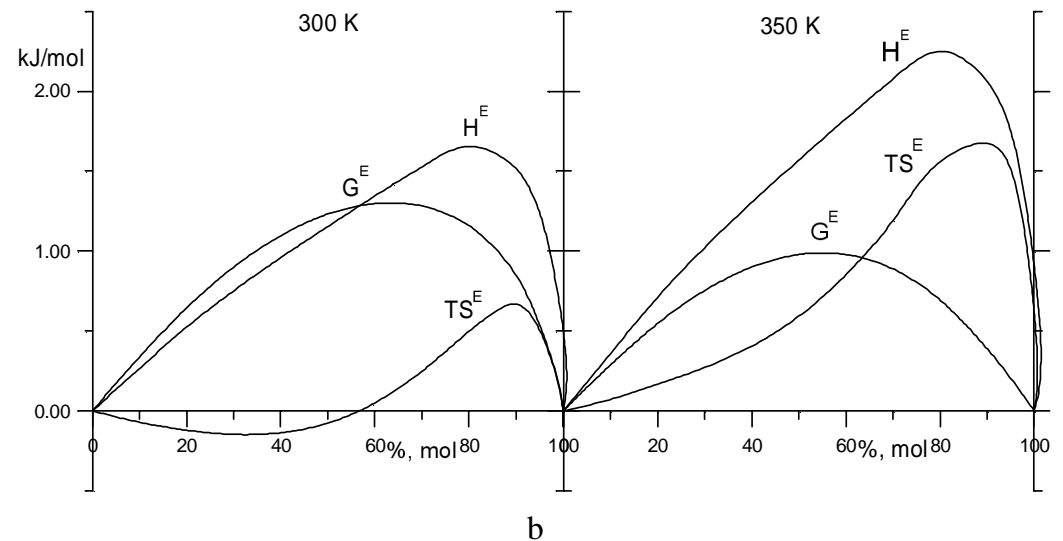

Fig. 2b. The thermodynamic functions of mixing of the acetic acid in the acrylic acid

As follows from the data in Table 5, the magnitudes of all these three parameters grow from 1,2-dichloroethane to the acetic acid. Notably, the magnitude of the enthalpy of mixing, the excess Gibb's energy, as well as the magnitude of the deviation of the solutions from the ideal solutions grow in the same order. Then it may be concluded that the increase of the solvent molecular refraction, DimrothReichardt parameter, as well as the $A N$, increases the deviation from the behavior of the ideal solution and the enthalpy of mixing.

\section{Conclusions}

Noteworthy, all systems (and within the whole range of the acrylic acid concentrations and temperatures) exhibited positive magnitudes of their excess Gibbs energy of mixing, suggesting the like deviation from the Raoult's law. The same positive change was observed in the enthalpy of mixing, indicating the acrylic acid dissolution was endothermic. Additionally, since the magnitude of that change enthalpy of mixing was also seen to increase with $T$, the change heat capacity as the result of the solution was also positive.

\section{References}

[1] Van-Chin-Syan Yu., Kochubei V., Sergeev V. et al.: Zh. Phys. Khim., 1996, 70, 1789.

[2] Halatin I., Van-Chin-Syan Yu., Kochubei V. et al.: Voprosy Khim. i Khim. Techn., 2005, 1, 55.

[3] Halatin I., Van-Chin-Syan Yu., Kochubei V. et al.: Voprosy Khim. i Khim. Techn., 2006, 4, 28.

[4] Pilugin A., Konopleva T. and Luzyanina G.: Zh. Prykl. Khimii, 1983, 56, 1723.

[5] Eck B. and Maurer G.: Fluid Phase Equilibrium, 2003, 2, 281.

[6] Tu C.-H., Wu Y.-S. and Liu T.-L.: Fluid Phase Equilibrium, 1997, 135, 97.

[7] Chubarov G., Danov S. and Balashov A.: Deposited Doc., ONIITEHIM Cherkasy (Ukraine), 10.03.89, N259-hp89.

[8] Chubarov G., Danov S. and Efremov R.: Zh. Prykl. Khimii, 1974, 47, 2130.

[9] Chubarov G., Danov S. and Balashov A.: Zh. Prykl. Khimii, 1989, 62, 331.
[10] Frolov A., Loginova M. and Saprykina A.: Zh. Prykl. Khimii, 1962, 10, 2282.

[11] Danov S., Obmelyuhina T. and Chubarov G.: Zh. Prykl. Khimii, 1990, 63, 596.

[12] Dolgopolov A., Obmelyuhina T. and Danov S.: Zh. Prykl. Khimii, 1991, 64, 1994.

[13] Wilson G.: J. Amer. Chem. Soc., 1964, 86, 135.

[14] Renon H. and Prausnitz J.: Ind. Eng. Chem., 1968, 2, 220.

[15] Abrams D. and Prausnitz J.: AIChE J., 1975, 21, 116.

[16] Belousov V. and Morachevsky A.: Khimiya i Termodinamica Rastvorov, Khimiya, Leningrad 1964.

[17] Belousov V. and Morachevsky A.: Teplota Gydkikh Smesei. Khimiya, Leningrad 1970.

[18] Boublik T., Fried V. and Hala E.: The Vapour Pressure of Pure Substances. Elsevier, Amsterdam 1973.

[19] Makitra R., Turovsky A. and Zaikov G.: Correlation Analysis in Chemistry Solutions., Brill Academic Publishers, New York 2004.

[20] Makitra R., Turovsky A. and Zaikov G.: Liquid Phase Correlation Analysis in the Chemistry of Solutions. Nova Science Publishers, New York 2007.

[21] Dimroth K., Reichardt C. and Siepmann T.: Leibigs Annallen der Chemie, 1963, 661, 1.

[22] Mayer U., Gerder W. and Gutman V.: Monatshefte für Chemie, 1977, 108, 1.

[23] Kos Yu.: PhD thesis, Lviv Polytechnic National University, Ukraine 2010.

[24] Kos Yu., Serheyev V. and Van-Chin-Syan Yu.: Visnyk Lvivskogo Nationalnogo Universitety. Khimiya, 2010, 51, 256.

\section{ТЕРМОДИНАМІЧНІ ВЛАСТИВОСТІ РОЗЧИНІВ АКРИЛОВОЇ КИСЛОТИ В 1,2-ДИХЛОРЕТАНІ ТА ОЦТОВІЙ КИСЛОТІ}

Анотація. Статичним тензиметричним методом виміряний тиск насиченої пари над розчинами акрилової кислоти в 1,2-дихлоретані та оцтовій кислоті в температурному інтервалі 295-355 К. За даними температурної залежності тиску насиченої пари розраховано склад рівноважних фаз та коефіцієнти активності компонентів. За температурною та концентраційною залежністю коеріиієнтів активності розраховані надлишкові термодинамічні функиії змішування досліджених розчинів $\left(H^{E}, G^{E}, S^{E}\right)$.

Ключові слова: акрилова кислота, тиск насиченої пари, коефіцієнти активності, рівновага рідина-пара, надлишкові термодинамічні функиї змімування. 